\title{
Application of porous materials in oil substances separation from water
}

\author{
Adam Gołub ${ }^{1, *}$, and Janina Piekutin ${ }^{1}$ \\ ${ }^{1}$ Bialystok University of Technology, Department of Technology in Engineering and Environmental \\ Protection, ul. Wiejska 45A, 15-351 Białystok, Poland
}

\begin{abstract}
The aim of the study was to determine the ability of the four porous materials: birch bark, cork, glass wool, and polyurethane foam to reduce the mineral oil index and the concentration of n-alkanes $\mathrm{C}_{7} \mathrm{H}_{16}-\mathrm{C}_{38} \mathrm{H}_{78}$ as well as to select the most efficient materials. Model solutions of gasoline, diesel oil, and distilled water with the following values of mineral oil index were prepared to tests: $52 \mu \mathrm{g} / \mathrm{dm}^{3}, 68 \mu \mathrm{g} / \mathrm{dm}^{3}$ and $73 \mu \mathrm{g} / \mathrm{dm}^{3}$. Then, studies were carried out using a dynamic method, wherein the columns were filled with adsorbents tested, and in each of three testing series, $500 \mathrm{~mL}$ of the model solution at constant bed load of $1,0551 \mathrm{~m}^{3} / \mathrm{m}^{2} \mathrm{~h}$ was filtered through the column. After filtration, the collected sample had volume of $250 \mathrm{~mL}$. The collected samples were subject to determination of mineral oil index and concentrations of n-alkanes from $\mathrm{C}_{7} \mathrm{H}_{16}$ to $\mathrm{C}_{38} \mathrm{H}_{78}$. Studies have shown that the most effective materials to lower the mineral oil index and the concentrations of $\mathrm{n}$-alkanes in water are birch bark and glass wool.
\end{abstract}

\section{Introduction}

The composition of oil pollution getting into the water varies, but it is mostly a crude oil and its derivatives (fuels, lubricants) [1]. There are many sources of such substances in water. The most important are: natural exudation of oil from the seabed and the ocean, drilling in the sea bottom, leaking of installations for extraction and transportation of oil, river and sea transport, emergency splashes (e.g. as a result of a tankers collision or crash), road and air transport, petroleum waste from industrial installations, storm water from urban areas [2-6]. Petroleum products spilled on the surface of water immediately spread in all directions, seeking to obtain the thinnest possible layer on the surface. The process of spreading is dependent on the viscosity of petroleum products, wind power, flow velocity, size of water reservoir, water waving, and type of medium [7].

Removal of oil contamination from water is a very complex process that is influenced by many factors: type of the oil, properties of water-oil emulsion (chemical or mechanical), degree of dispersion, presence of other compounds in water (e.g. emulsifiers, stabilizers, surfactants). For this reason, there is no universal method for oil removal usable in any situation [8].

\footnotetext{
* Corresponding author: adamgolub92@gmail.com
} 
There are many different methods for removal of toxic oils from the water. One such method is based on sorption, i.e. the physical method of de-oiling, during which two processes occur simultaneously: absorption of oil within the pores and voids of sorbent as well as oil adsorption on its surface $[6,15]$. Among sorbents, materials of a porous nature are the most commonly used. They are solids having a high specific surface area resulting from the presence of a system of open and closed spaces, where adsorption of the substance occurs. Sorbents are readily available materials, easy to use, inexpensive, and environment friendly [7].

The aim of the study is to determine the ability of the four porous materials: birch bark, cork, glass wool, and polyurethane foam to reduce the mineral oil index and the concentrations of n-alkanes $\mathrm{C}_{7} \mathrm{H}_{16}-\mathrm{C}_{38} \mathrm{H}_{78}$ as well as to select the most efficient materials in this view.

\section{Materials and methods}

\subsection{Subject of research: porous materials}

In order to conduct the study upon removal of the oil substances from model water, 4 porous materials were used: birch bark, cork, glass wool, and polyurethane foam. Birch bark and cork were mechanically ground to obtain a particle size of $0.1-1 \mathrm{~mm}$. Glass wool was cut into small squares of $2 \times 2 \mathrm{~cm}$. Pieces of polyurethane foam had dimensions of $1 \times 1 \mathrm{~cm}$.

Basic model water consisted of distilled water enriched with a mixture of fuels: gasoline and diesel oil. The study included petroleum products expressed as a mineral oil index (IOM) and aliphatic hydrocarbons $\left(\mathrm{C}_{7} \mathrm{H}_{16}\right.$ to $\left.\mathrm{C}_{38} \mathrm{H}_{78}\right)$. The testing included model water at three difference IOM and n-alkanes concentrations describing them with adequate series. The first series was IOM: $52 \mu \mathrm{g} / \mathrm{dm}^{3}$ and $\sum \mathrm{n}$-alkanes $8.3940 \mu \mathrm{g} / \mathrm{dm}^{3}$, the second series consisted of IOM $68 \mu \mathrm{g} / \mathrm{dm}^{3}, \sum$ n-alkanes $9.4276 \mu \mathrm{g} / \mathrm{dm}^{3}$, while the third one IOM $73 \mu \mathrm{g} / \mathrm{dm}^{3}, \sum \mathrm{n}$-alkanes $10.4276 \mu \mathrm{g} / \mathrm{dm}^{3}$.

Table 1. The results of determination of mineral oil index and concentrations of n-alkanes $\mathrm{C}_{7} \mathrm{H}_{16-}$ $\mathrm{C}_{38} \mathrm{H}_{78}$ in model solutions used for the tests.

\begin{tabular}{|c|c|c|c|c|c|c|c|}
\hline \multirow{2}{*}{ Additive } & \multicolumn{3}{|c|}{ Model solution $\left[\boldsymbol{\mu g} / \mathbf{d m}^{3}\right]$} & \multirow{2}{*}{ Additive } & \multicolumn{3}{|c|}{ Model solution $\left[\boldsymbol{\mu g} / \mathbf{d m}^{3}\right]$} \\
\cline { 2 - 3 } & $\mathbf{5 2}$ & $\mathbf{6 8}$ & $\mathbf{7 3}$ & & $\mathbf{5 2}$ & $\mathbf{6 8}$ & $\mathbf{7 3}$ \\
\hline $\mathrm{IOM}$ & 51.6 & 67.8 & 73.1 & $\mathrm{C}_{23} \mathrm{H}_{48}$ & 0.0039 & 0.0069 & 0.006 \\
\hline $\mathrm{C}_{7} \mathrm{H}_{16}$ & 0.0011 & 0.0031 & 0.0044 & $\mathrm{C}_{24} \mathrm{H}_{50}$ & 0.0287 & 0.0329 & 0.0383 \\
\hline $\mathrm{C}_{8} \mathrm{H}_{18}$ & 0.0014 & 0.0024 & 0.0023 & $\mathrm{C}_{25} \mathrm{H}_{52}$ & 0.3259 & 0.4064 & 0.4638 \\
\hline $\mathrm{C}_{9} \mathrm{H}_{20}$ & 0.0078 & 0.0073 & 0.008 & $\mathrm{C}_{26} \mathrm{H}_{54}$ & 0.4299 & 0.5359 & 0.4811 \\
\hline $\mathrm{C}_{10} \mathrm{H}_{22}$ & 0.1053 & 0.1128 & 0.1485 & $\mathrm{C}_{27} \mathrm{H}_{56}$ & 0.0109 & 0.0148 & 0.0125 \\
\hline $\mathrm{C}_{11} \mathrm{H}_{24}$ & 0.2163 & 0.2466 & 0.2449 & $\mathrm{C}_{28} \mathrm{H}_{58}$ & 0.0892 & 0.0957 & 0.0787 \\
\hline $\mathrm{C}_{12} \mathrm{H}_{26}$ & 0.157 & 0.1913 & 0.1867 & $\mathrm{C}_{29} \mathrm{H}_{60}$ & 0.6992 & 0.7094 & 0.7346 \\
\hline $\mathrm{C}_{13} \mathrm{H}_{28}$ & 0.0298 & 0.0379 & 0.0364 & $\mathrm{C}_{30} \mathrm{H}_{62}$ & 0.845 & 0.9087 & 0.7509 \\
\hline $\mathrm{C}_{14} \mathrm{H}_{30}$ & 0.0058 & 0.0064 & 0.0058 & $\mathrm{C}_{31} \mathrm{H}_{64}$ & 0.1084 & 0.1173 & 0.1988 \\
\hline $\mathrm{C}_{15} \mathrm{H}_{32}$ & 0.0046 & 0.0065 & 0.0084 & $\mathrm{C}_{32} \mathrm{H}_{66}$ & 1.7973 & 1.8624 & 2.1507 \\
\hline $\mathrm{C}_{16} \mathrm{H}_{34}$ & 0.0042 & 0.0067 & 0.0077 & $\mathrm{C}_{33} \mathrm{H}_{68}$ & 1.3796 & 1.4497 & 2.1261 \\
\hline $\mathrm{C}_{17} \mathrm{H}_{36}$ & 0.0125 & 0.0893 & 0.1185 & $\mathrm{C}_{34} \mathrm{H}_{70}$ & 0.006 & 0.0151 & 0.0361 \\
\hline $\mathrm{C}_{18} \mathrm{H}_{38}$ & 0.1125 & 0.1461 & 0.1552 & $\mathrm{C}_{35} \mathrm{H}_{72}$ & 0.1363 & 0.2286 & 0.5075 \\
\hline $\mathrm{C}_{19} \mathrm{H}_{40}$ & 0.1147 & 0.1497 & 0.2206 & $\mathrm{C}_{36} \mathrm{H}_{74}$ & 1.4998 & 1.7223 & 1.3425 \\
\hline $\mathrm{C}_{20} \mathrm{H}_{42}$ & 0.0069 & 0.0075 & 0.0096 & $\mathrm{C}_{37} \mathrm{H}_{76}$ & 0.0069 & 0.004 & 0.0067 \\
\hline $\mathrm{C}_{21} \mathrm{H}_{44}$ & 0.0135 & 0.0159 & 0.0227 & $\mathrm{C}_{38} \mathrm{H}_{78}$ & 0.0748 & 0.081 & 0.0823 \\
\hline $\mathrm{C}_{22} \mathrm{H}_{46}$ & 0.1588 & 0.207 & 0.2313 & $\sum \mathrm{n}-\mathrm{alkanes}$ & 8.3940 & 9.4276 & 10.4276 \\
\hline
\end{tabular}




\subsection{Methodology of technological research}

The removal process was conducted using a dynamic method applying model water with different concentrations of petroleum substances. Volume of $500 \mathrm{~mL}$ of model solution at constant load of the filter bed $1.0551 \mathrm{~m}^{3} / \mathrm{m}^{2} \mathrm{~h}$ was filtered through the column filled with adsorbent (porous material); after filtration, the collected sample volume was $250 \mathrm{~mL}$. All materials for the experiment were washed with distilled water.

\subsection{Methodology of analytical testing}

The collected samples were subject to determination of the mineral oil index (IOM) and the concentrations of n-alkanes from $\mathrm{C}_{7} \mathrm{H}_{16}$ to $\mathrm{C}_{38} \mathrm{H}_{78}$. Determinations of individual samples were performed using gas chromatograph coupled with mass spectrometer VARIAN 4000. Separation of analytes was conducted on a column VF-5MS of dimensions $30 \mathrm{~m} \times 0.25 \mathrm{~mm} \times 0.2 \mathrm{~mm}$. The stationary phase for the column was composed of polydimethylsiloxane with $5 \%$ share of phenyl groups.

Procedure for preparing the sample for analysis was divided into several stages: fixing, extraction, purification, and concentration. The sample fixing process consisted of acidification using inorganic acid up to a $\mathrm{pH}$ of about 2 .

For the isolation of compounds included in the n-alkanes mixture, the liquid-liquid extraction system was applied. The isolation process was carried out at room temperature equal to $\pm 20^{\circ} \mathrm{C}$ on a magnetic stirrer at a speed of about $800 \mathrm{rpm}$, with $50 \mathrm{~mL}$ of dichloromethane and hexane mixture at a volume ratio of 2:1. After separation of aqueous and organic layers, the eluate was transferred to a volumetric flask and then subjected to florisil treatment and drying over anhydrous sodium sulfate p.a. The extract was separated from the water sample and concentrated to a volume of $1.5 \mathrm{~mL}$. Concentrated extract was subject to separation and detection on the GC/MS system applying the following parameters:

- $\quad$ volume of injected sample: $1 \mu \mathrm{L}$,

- $\quad$ no splitting the carrier gas stream (splittless mode),

- injector temperature: $250{ }^{\circ} \mathrm{C}$,

- carrier gas flow rate: $1 \mathrm{~mL} / \mathrm{min}$,

- initial oven temperature: $40^{\circ} \mathrm{C}$ - isothermal 5 minutes,

- final oven temperature: $300{ }^{\circ} \mathrm{C}$ - isothermal 20 minutes,

- temperature increment: $10^{\circ} \mathrm{C} / \mathrm{min}$,

- transfer line temperature: $230^{\circ} \mathrm{C}$,

- $\quad$ ion source temperature: $180^{\circ} \mathrm{C}$,

- $\quad$ arrange of scanned masses: $40-400 \mathrm{~m} / \mathrm{z}$.

The carrier gas: helium of 6.0 purity.

The results of the test substances contents are the average of three replicates.

\section{Results and discussion}

The effectiveness of lowering the mineral oil index and the sum of the concentrations of $\mathrm{n}$ alkanes $\mathrm{C}_{7} \mathrm{H}_{16}-\mathrm{C}_{38} \mathrm{H}_{78}$ on materials used for the tests are shown in Figure 1. The maximum degree of IOM removal for particular sorbents is: $82 \%$ in the case of birch bark, $78.8 \%$ for glass wool, $74.8 \%$ for cork, and $73.2 \%$ for the polyurethane foam. The highest degree of n-alkanes sum removal, however, is as follows: birch bark $97.1 \%$, glass wool $96.8 \%$, cork $95.7 \%$, polyurethane foam $95.5 \%$. Efficiency of removal of both the IOM and n-alkanes can be ranked as follows: birch bark, glass wool, cork, polyurethane foam. 

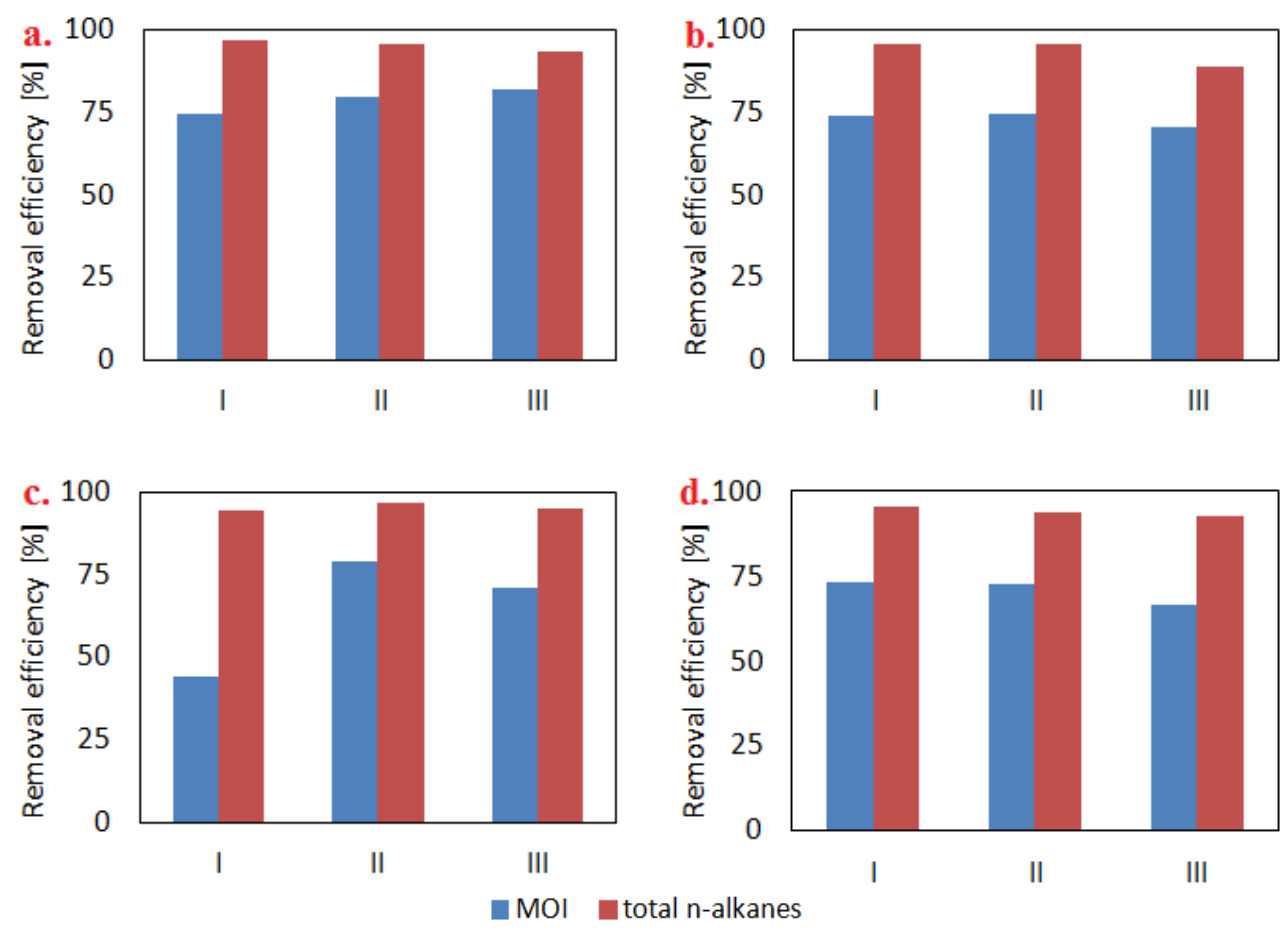

Fig. 1. Comparing the degree of removal of mineral oil index and the sum of $n$-alkanes $\mathrm{C}_{7} \mathrm{H}_{16}-\mathrm{C}_{38} \mathrm{H}_{78}$ by individual porous materials from model water after sorption process: a. birch bark, b. cork, c. glass wool, d. polyurethane foam.

In Figure 2, a bar graph indicates the degree of removal of particular n-alkanes, and a line graph indicates the concentration of each n-alkanes after the sorption process. It was found that tested sorbents removed below $70 \%$ of n-alkanes as follows: $\mathrm{C}_{7} \mathrm{H}_{16}, \mathrm{C}_{8} \mathrm{H}_{18}$, $\mathrm{C}_{14} \mathrm{H}_{30}-\mathrm{C}_{18} \mathrm{H}_{38}, \mathrm{C}_{20} \mathrm{H}_{42}, \mathrm{C}_{21} \mathrm{H}_{44}, \mathrm{C}_{23} \mathrm{H}_{48}, \mathrm{C}_{37} \mathrm{H}_{76}$ and $\mathrm{C}_{38} \mathrm{H}_{78}$. The best removal effect - above $90 \%$ - was achieved for the following n-alkanes removal: $\mathrm{C}_{9} \mathrm{H}_{20}, \mathrm{C}_{11} \mathrm{H}_{24}, \mathrm{C}_{12} \mathrm{H}_{26}, \mathrm{C}_{22} \mathrm{H}_{46}$, $\mathrm{C}_{25} \mathrm{H}_{52}, \mathrm{C}_{26} \mathrm{H}_{54}, \mathrm{C}_{29} \mathrm{H}_{60}-\mathrm{C}_{36} \mathrm{H}_{74}$.

It has been found (Figure 2) that in the first series of tests, over $95 \%$ removal was obtained for $17 \mathrm{n}$-alkanes in the case of birch bark, 16 for the cork, 14 for polyurethane foam, and 13 for glass wool. In the second series of studies, above 95\% removal for $17 \mathrm{n}$-alkanes using birch bark and cork was recorded, for 16 n-alkanes using glass wool, and for 14 using polyurethane foam. In the third series of tests, more than $95 \%$ of $16 \mathrm{n}$-alkanes was removed in the case of birch bark, and glass wool, 10 in the case of polyurethane foam and 6 in the case of cork. For all series of tests, over $95 \%$ removal was obtained for 50 n-alkanes using birch bark, 45 using glass wool, 39 applying cork, and 38 using polyurethane foam. 

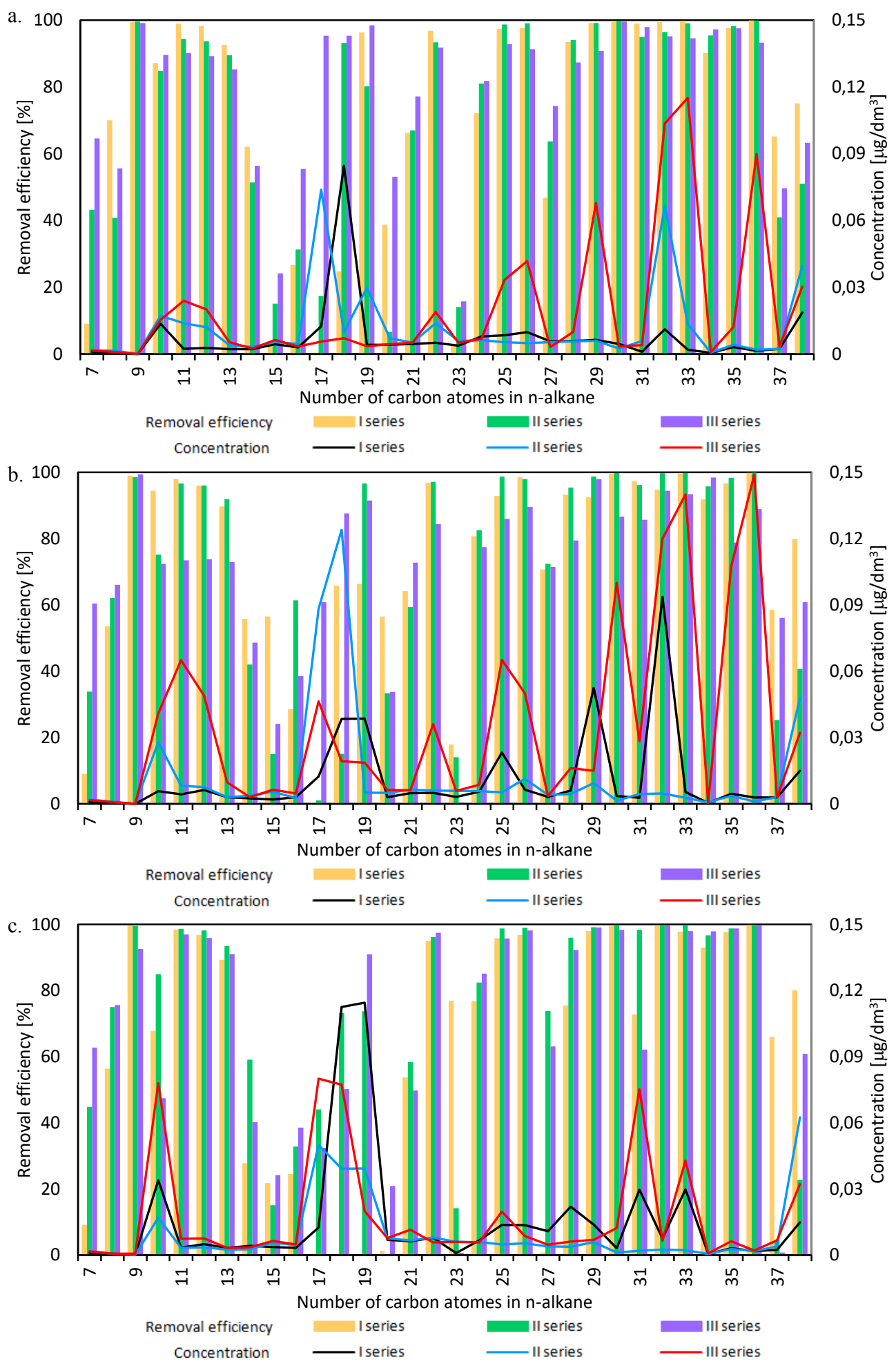


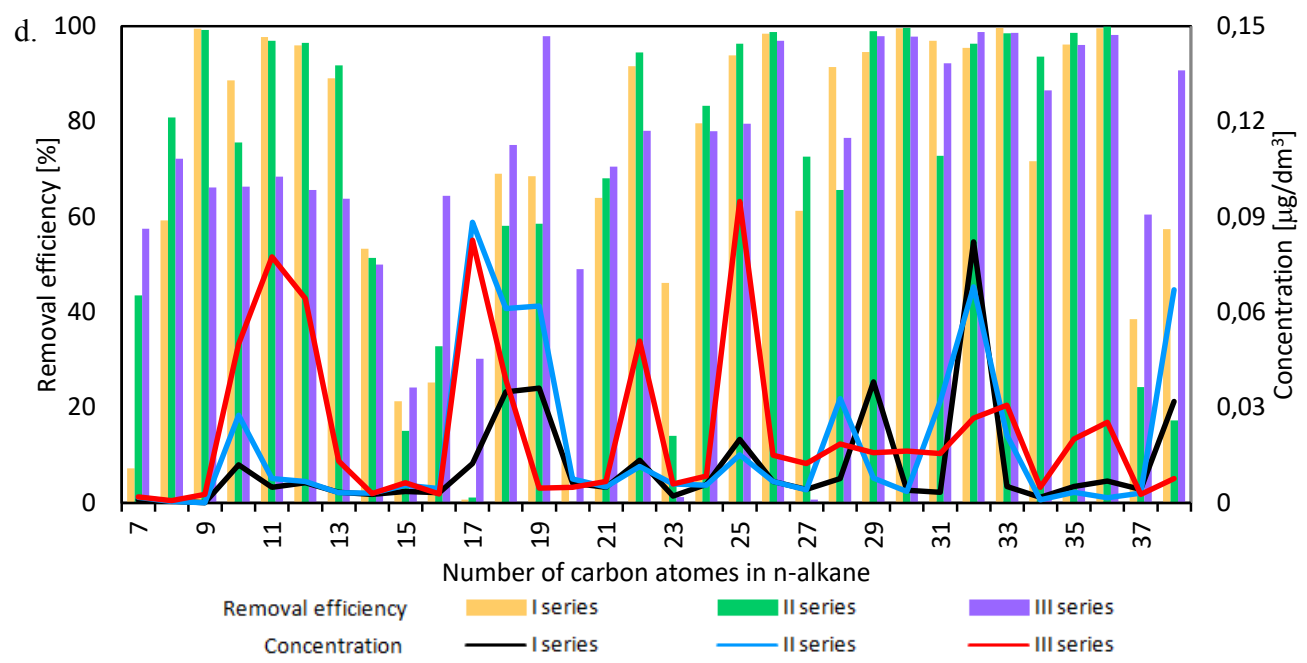

Fig. 2. Comparison of removal efficiency of n-alkanes $\mathrm{C}_{7} \mathrm{H}_{16}-\mathrm{C}_{38} \mathrm{H}_{78}$ and their concentrations in solutions after sorption process on individual porous materials: a) birch bark, b) cork, c) glass wool, d) polyurethane foam.

Sorbents are materials with high affinity to oils and a little to water, which due to two simultaneously occurring processes: adsorption (involving the oil adhesion to the surface of the sorbent, the extent of which depends on the viscosity of the oil) and absorption (consisting in filling the pores of the material by oil, which can be taken out of the water along with the sorbent due to the capillary force) allow for the removal of toxic oil substances from water in a non-invasive manner [9]. Among the most important material properties affecting the efficiency of oil removal from water, a high absorption capacity is mentioned in relation to the most of the oily substances [10-17]. The experiment demonstrated that the most effective materials in lowering the n-alkanes concentrations within the range of $\mathrm{C}_{7} \mathrm{H}_{16}-\mathrm{C}_{38} \mathrm{H}_{78}$ (these alkanes compose the oil contamination [2]) include birch bark and glass wool.

Studies describing the separation of oil contamination from water by sorbents tend to focus on the removal degree of the total content of oily substances without considering of lowering the concentration of the individual components. Some of these studies [18] report that loose natural wool fibers are able to absorb $74 \%$ of oil pollution from water, the recycled wool-based nonwoven material - 78\%, while inorganic sorbent sepiolite absorbs up to $86 \%$ of oil pollution. Other studies [19] indicate that the silkworm coco on waste reduces the amount of oil by more than $50 \%$ after 20 minutes contact with the model solution. Maximum removal efficiencies obtained in the above experiment are higher than those given in the literature, however, it should be noted that in the cited literature data, a total mass of removed oily substances was the basis for the sorbent efficiency determination, while in the present experiment, there were petroleum products expressed as IOM and hydrocarbons of n-alkanes group.

\section{Summary and Conclusions}

Based on the studies, it was found that the applied porous materials removed the oil substances with varying efficiencies. It was also shown that not all of them remove at the same time the IOM and tested aliphatic hydrocarbons. Achieved results make it possible for a broader analysis of their application in the sorption process of oil products from water. The experiment compared the degree of mineral oil index removal and concentrations of n-alkanes $\mathrm{C}_{7} \mathrm{H}_{16}-\mathrm{C}_{38} \mathrm{H}_{78}$ during sorption on 4 porous materials: birch bark, cork, glass wool, 
and polyurethane foam. After analyzing the test results, the following conclusions can be drawn:

- birch bark is characterized by the maximum effectiveness in reducing both IOM and the concentration of n-alkanes,

- glass wool is characterized by high removal efficiency of n-alkanes at various concentrations of oily substances in water,

- polyurethane foam is the least efficient in terms both of the IOM reduction and concentration of n-alkanes.

\section{References}

1. W. Meissner, Wiadomości ekologiczne 51, 1, 17-34 (2005)

2. T. Graczyk, Ł. Piskorski, Protecting marine environment from petroleum pollution (Wydawnictwo Uczelniane Politechniki Szczecińskiej, Szczecin, 1996) (in Polish)

3. J.M. Gutteter-Grudziński, Study on the efficiency of deoiling bilge water using hydrocyclone sections and coalescing porous baffles (Wydawnictwo Naukowe Akademii Morskiej w Szczecinie, Szczecin, 2012) (in Polish)

4. Ż. Polkowska, M. Błaś, Presence of selected groups of compounds in water from the airport plate. State and anthropogenic changes of water quality in Poland (Wydawnictwo Uniwersytetu Łódzkiego, Łódź, 2010) (in Polish)

5. Z. Pruszak, Sea water. An outline of physical processes and environmental engineering (Wydawnictwo IBW PAN, Gdańsk, 2003) (in Polish)

6. W. Wawrzyniak, Seas and oceans pollution. Sources and substances (Wydawnictwo Uczelniane Politechniki Szczecińskiej, Szczecin, 2004) (in Polish)

7. W. J. Tic, P. M. Pijarowski, Przem. Chem. 94, 3 301-306 (2015)

8. E. Gomółka, Ochr. Sr. 463/1, 23, 39-43 (1985)

9. A. Norizan, E. Mohanad, A. Ayman, Y. Chun-Yang, Environ. Technol. 33, 4, 481-486 (2012)

10. M.O. Adebajo, R.L. Frost, J.T. Kloprogge, O. Carmody, J. Porous Mat. 10, 3, 159-170 (2003)

11. A. Bayat, G. Vakili-Nezhaad, Chem. Eng. Technol. 28, 12, 1525-1528 (2005)

12. O.A. Galblaub, I.G. Shaykhiev, S.V. Stepanova, G. Timirbaeva, Process Saf. Environ. 101, 88-92 (2016)

13. M. Husseien, A.A. Amer, A. El-Maghraby, N.A. Taha, Int. J. Environ. Sci. Te. 6, 1, 123-130 (2009)

14. C. Hyungmin, M.C. Rinn, Environ. Sci. Technol. 26, 772-776 (1992)

15. Z. Jiang, J. Ge, Y. Zhou, Z. Wang, D. Chen, S. Yu, H. Jiang, NPG Asia Materials, 8 (2016)

16. M. Radetic, V. Ilic, D. Radojevic, R. Miladinovic, D. Jocic, P. Jovancic, Chemosphere 70, 525-530 (2008)

17. O.V. Rotar, D.V. Iskrizhitskaya, A.A. Iskrizhitsky, A.A. XV International Scientific Conference Chemistry and Chemical Engineering in XXI century, 145-150 (2014)

18. V. Rajakovic, G. Aleksic, M. Radetic, Lj. Rajakovic, J. Hazard Mater. 143, 494-499 (2007)

19. H. Moriwaki, S. Kitajima, M. Kurashima, A. Hagiwara, K. Haraguchi, K. Shirai, R. Kanekatsu, K. Kiguchi, J. Hazard Mater. 165, 266-270 (2009) 